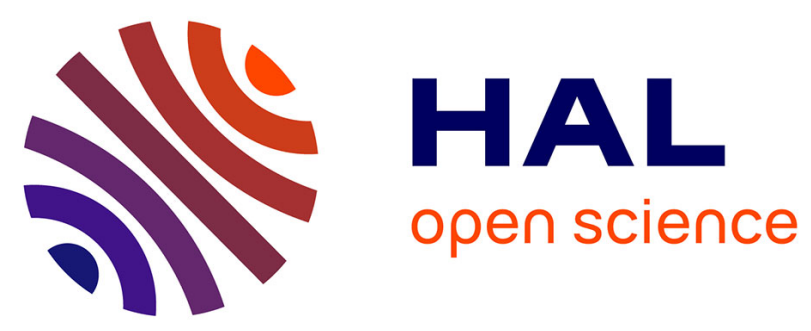

\title{
Improving microcystin monitoring relevance in recreative waters: A regional case-study (Brittany, Western France, Europe)
}

Frédéric Pitois, Chantal Vezie, Isabelle Thoraval, Estelle Baurès

\section{- To cite this version:}

Frédéric Pitois, Chantal Vezie, Isabelle Thoraval, Estelle Baurès. Improving microcystin monitoring relevance in recreative waters: A regional case-study (Brittany, Western France, Europe). International Journal of Hygiene and Environmental Health, 2016, 219 (3), pp.288-293. 10.1016/j.ijheh.2015.12.004 . hal-01255825

HAL Id: hal-01255825

https://hal-univ-rennes1.archives-ouvertes.fr/hal-01255825

Submitted on 14 Jan 2016

HAL is a multi-disciplinary open access archive for the deposit and dissemination of scientific research documents, whether they are published or not. The documents may come from teaching and research institutions in France or abroad, or from public or private research centers.
L'archive ouverte pluridisciplinaire HAL, est destinée au dépôt et à la diffusion de documents scientifiques de niveau recherche, publiés ou non, émanant des établissements d'enseignement et de recherche français ou étrangers, des laboratoires publics ou privés. 
Elsevier Editorial system(tm) for

International Journal of Hygiene and Environmental Health

Manuscript Draft

Manuscript Number: IJHEH-D-15-00272R1

Title: Improving Microcystin monitoring relevance in recreative waters: a regional case-study (Brittany, Western France, Europe)

Article Type: Original Article

Keywords: Cyanobacteria; microcystin; monitoring efficiency; exposure; public health survey

Corresponding Author: Dr. Frédéric Pitois, Ph.D.

Corresponding Author's Institution: Limnologie sarl

First Author: Frédéric Pitois, Ph.D.

Order of Authors: Frédéric Pitois, Ph.D.; Chantal Vezie, Ph.D.; Isabelle Thoraval, MSc; Estelle Baurès, Ph.D.

Abstract: Cyanobacteria and their toxins are known as a health hazard in recreative and distributed waters. Monitoring data from 2004 to 2011 were collected at regional scale to characterize exposition parameters to microcystins in Brittany (Western France). The data show that cyanobacteria populations are experiencing a composition shift leading to a longer duration of cell densities higher than WHO alert levels 2 and 3. Microcystins however appear to be more frequently detected with subacute concentrations in low cell density samples than in high cell density samples or during bloom episodes. Positive relations are described between microcystin concentrations, detection frequencies and cyanobacteria biovolumes, allowing for a novel definition of alert levels and decision framework following WHO recommendations. 
Improving Microcystin monitoring relevance in recreative waters: a regional case-study (Brittany, Western France, Europe)

Authors : Frédéric Pitois ${ }^{\mathrm{a}, \mathrm{b}, \mathrm{c}}$, Chantal Vezie ${ }^{\mathrm{a}}$, Isabelle Thoraval ${ }^{\mathrm{a}}$, Estelle Baurès ${ }^{\mathrm{b}, \mathrm{c}}$

Authors affiliation :

a- Limnologie sarl, 16 rue Paul Langevin, 35200 Rennes, France

b- EHESP Rennes, Sorbonne Paris Cité, Avenue du Professeur Léon Bernard, CS 74312, 35043 Rennes

Cedex, France

c- Inserm, U 1085-IRSET, LERES, France

Authors mail adress :

Frédéric Pitois: fred.pitois@limnosphere.com

Chantal Vezie: chantal.vezie@limnosphere.com

Isabelle Thoraval: isabelle.thoraval@limnosphere.com

Estelle Baurès: estelle.baures@ehesp.fr

Corresponding author:

Frédéric Pitois, Limnologie sarl, 16 rue Paul Langevin, 35200 Rennes, France

fred.pitois@limnosphere.com 


\section{Abstract}

Cyanobacteria and their toxins are known as a health hazard in recreative and distributed waters. Monitoring data from 2004 to 2011 were collected at regional scale to characterize exposition parameters to microcystins in Brittany (Western France). The data show that cyanobacteria populations are experiencing a composition shift leading to a longer duration of cell densities higher than WHO alert levels 2 and 3 . Microcystins however appear to be more frequently detected with subacute concentrations in low cell density samples than in high cell density samples or during bloom episodes. Positive relations are described between microcystin concentrations, detection frequencies and cyanobacteria biovolumes, allowing for a novel definition of alert levels and decision framework following WHO recommendations.

\section{Keywords:}

Cyanobacteria, microcystin, monitoring efficiency, exposure, public health survey 


\section{1- Introduction}

Toxic cyanobacteria are known as a potential health hazard since the 1990s, and three major exposure routes are currently recognized: i) through dermal contact and accidental inhalation/ingestion during recreational activities in raw waters (Osborne et al., 2007; Stewart et al., 2006; Baker et al., 2008 and 2010); ii) through ingestion of drinking water produced from a contaminated resource (Byth, 1980; Griffiths and Saker, 2003; Merel et al., 2013) and iii) through the ingestion of cyanobacteria-based food ingredients, either directly as dietary compliments (Gilroy et al., 2000; Heussner et al., 2012; Rellan et al., 2009; Vichi et al., 2012) or indirectly via contaminated seafood, fishes or shellfishes (Ibelings and Chorus, 2007). Low-level chronic exposure through these routes is currently suspected of the highest human health impact (Spoof, 2005; Li et al., 2011, Wierich and Miller; 2014).

Water exposition routes are the most documented since the publication of WHO provisional guidelines for recreative and treated waters (Chorus and Bartram, 1999). Recreational water surveys involve a tiered management framework based on biomass proxies (chlorophyll a, cyanobacteria cell density), and the proposed decision scheme has been implemented by most countries where cyanobacteria are monitored (Ibelings et al., 2014). To summarize, this decision framework requires cyanobacteria to be quantified, and cell densities to be compared to Alert Level values: Alert Level 2 (20000 cell/ml) implies water users information, whereas above Alert Level 3 (100 $000 \mathrm{cell} / \mathrm{ml})$ microcystin occurrence is likely and microcystin analysis is recommended. Microcystin concentrations are then compared with guideline values calculated according to a daily No Observed Adverse Effect Level (NOAEL) intake of $40 \mu \mathrm{g} / \mathrm{kg}$ bodyweight (Falconer et al., 1994; Codd et al., 2005). WHO guideline for recreational activity suspension is $20 \mu \mathrm{g} / \mathrm{l}$ microcystin LR, whereas French regulation, based on different intake hypotheses, adopted a chronic exposure guideline of $13 \mu \mathrm{g} / \mathrm{l}$ and an acute exposure guideline of $80 \mu \mathrm{g} / \mathrm{l}$ since 2013.

While proliferation episodes are widely documented and subjected to research work, chronic exposure, subacute toxin concentration and low-biomass effects are on the other hand less often 
considered. They can however be seen as a health hazard for particular populations such as children, pregnant women, asthmatic or atopic people... (Li et al., 2011; Weirich and Miller, 2014). Cyanobacterial toxins are for example known to be associated with carcinogenesis (Zegura et al., 2011), cytotoxicity ((Young et al., 2008) and have been shown to act as endocrine disruptors (Sychrova et al, 2012) or allergenic/pyrogenic agents, either as aerosols (Kirkpatrick et al., 2011 ; Cheng et al., 2007) or through direct contact with raw waters (Pilotto et al., 2004; Kirkpatrick et al., 2010 and 2011; Ohkouchi et al., 2015).

Public health surveys of recreational inland waters in Britany (north western France) are held since 2003, and monitoring data have shown subacute toxin concentrations to be the most frequently encountered. In this context the present exploitation of water quality data from 26 recreational lakes collected between 2004 and 2011 was aimed at answering two questions: first, does the current monitoring framework derived from the 1999 WHO recommendations accurately account for microcystin exposure in recreational waters? Secondly, if this is not the case how can it be improved in terms of exposure representation and cost efficiency?

\section{2- Materials and methods}

Our study is based on public health weekly survey data from 26 lakes used as recreational areas or water resources monitored every year from 2004 to 2011 in Brittany (north-western France, Figure 1). These sites were selected according to cyanobacteria survey continuity criteria. Only 26 sites out of a total of 40 could be considered as continuously monitored from June to September since 2004 .

Figure 1

Cyanobacteria data, i.e. cell densities and microcystin concentrations, were collected from the regional public health authorities (French Agence Régionale de Santé of Brittany). All samples were 
analyzed by four different local laboratories for cyanobacteria composition and microcystin concentration.

Cyanobacteria were identified and counted with light microscope according to Utermöhl (1958). All monitoring data were first examined as cell densities, to comply with WHO alert level thresholds (Chorus and Bartram, 1999), and then converted to cell biovolumes using mean cell dimensions obtained from cyanobacteria reference works (Geitler, 1932; Komarek and Anagnostidis, 1999 and 2005; Komarek, 2013) and relevant geometric formulas (US Environmental Protection Agency, 2010). This conversion was meant to account for differences in biomass contribution induced by larger taxa associated with lower cell densities (e.g. Microcystis, Woronichinia, etc.) vs. smaller taxa associated with larger cell densities (e.g. Aphanocapsa, Aphanothece, etc.).

All toxin analyses were conducted on the same samples used for species composition analysis. Toxin analyses were systematically performed on all samples reaching WHO alert level 3 , but could be performed on lower cell density (e.g. WHO alert level 2). Sample preparation involved a preliminary cyanobacteria cell lysis step with methanol (Lawrence et al., 2001) to account for total (dissolved and intra-cell) toxin concentrations. Depending on the laboratories, Microcystins (MCs) were analyzed either with LC/MS, HPLC or ELISA immunoassays. These methods quantification limits ranged from 0.05 to $0.2 \mu \mathrm{g} / \mathrm{L}$. All laboratory results were harmonized to a common quantification limit, i.e. 0.2 $\mu \mathrm{g} / \mathrm{L}$.

From 2004 to 2011 in Brittany, cyanobacteria were analyzed in 3278 water samples; MCs analyses were conducted on a total of 719 samples (i.e. $23 \%$ of all samples) and MCs were detected in 159 samples (i.e. $22 \%$ of all samples analyzed for MCs).

Frequency distribution analyses were carried out on grouped data with classes of 1,2 and $5.10^{\mathrm{i}}$ with $\mathrm{i}$ $=-1 ; 0 ; 1 ; 2$ for MCs concentrations, $i=4 ; 5 ; 6$ for cell densities, and $i=5 ; 6 ; 7$ for cell biovolumes.

The Monitoring Cost Index used from section 3.3 onwards was calculated in two steps. First the mean analytical cost at regional scale was calculated for the current situation, i.e. $23 \%$ samples analyzed 
for MCs. Then a new mean regional cost was estimated for any proportion of samples analyzed for MCs according to monitoring hypothesis.

Minimum biovolume thresholds were graphically derived from MCs concentration classes. These thresholds were defined as the minimal biovolume for a positive detection of MCs class (n-1). For MCs $=1 \mu \mathrm{g} / \mathrm{l}$ for example, the threshold biovolume was set as the minimum cell volume allowing an observation of $0.5<M C s<1 \mu \mathrm{g} / \mathrm{l}$; for a target MCs of $20 \mu \mathrm{g} / \mathrm{l}$, the threshold was the minimal biovolume giving $5<\mathrm{MCs}<10 \mu \mathrm{g} / \mathrm{l}$, etc...

\section{3- Results and discussion}

\section{1- Cyanobacteria occurrences and biomass}

All data together, maximal cell densities ranged every year from 1.9 to $6.510^{6} \mathrm{cell} / \mathrm{ml}$, with weekly average values from 10600 to $452000 \mathrm{cell} / \mathrm{ml}$. Quantile distributions of cell densities and WHO alert thresholds have already been described in a previous work (Pitois et al., 2014a). To summarize, the mean weekly values tended to increase regularly from 2004 to 2011, in particular because of an increase of the lower, spring densities (Figure 2). Cell densities above WHO alert level 2 (20000 cell $/ \mathrm{ml}$ ) accounted for $48 \%$ of all samples (from 41 to $57 \%$ results every year). WHO alert level 3 was exceeded in $23 \%$ of the data distribution, and in 22 to $31 \%$ of all samples. Maximal cell densities were usually observed in mid-summer, i.e. from July, $15^{\text {th }}$ to August, $25^{\text {th }}$. Peak densities tended however to occur earlier (i.e. July, $15^{\text {th }}-22^{\text {nd }}$ ) from 2006 to 2008 , and later (i.e. August, $15^{\text {th }}-25^{\text {th }}$ ) in 2004-2005 and from 2009 to 2011.

Figure 2

Maximum biovolumes ranged from 130 to $210.10^{6} \mu \mathrm{m}^{3} / \mathrm{ml}$, with mean weekly values from 4 to 9.9 $10^{6} \mu \mathrm{m}^{3} / \mathrm{ml}$ (Figure 3). Compared to cell densities evolution, cell biovolumes appeared almost 
constant: from one year to the other biovolume range covered 2 orders of magnitude whereas cell density variations could reach 4 to 5 orders.

Maximum cell biovolumes were usually observed in mid-summer (from July, $11^{\text {th }}$ to August, $16^{\text {th }}$ ) except for 2004 (early September). Maximal biovolume and cell density values were usually encountered in the same week from 2006 to 2010 but peak biovolumes appeared 2 weeks earlier in 2004-2005 and 7 weeks later in 2011.

Figure 3

The parallel observation of a gradual cell density increase while cell biovolume remained fairly constant over the years illustrates a shift in cyanobacterial species composition (Figure 4), with smaller size taxa replacing larger size species from 2008 onward. This is emphasized in Figure 4, showing in parallel an increase of the combined total cell density smaller Chroococcales such as Aphanothece sp., Aphanocapsa sp., Merismopedia sp. ... and a decrease of the combined cell density for Microcystis sp. and Anabaena sp. (largest taxa observed in Brittany).

Figure 4

\section{2- Microcystins concentrations and detection frequencies}

MCs concentrations appeared lower than $1 \mu \mathrm{g} / \mathrm{l}$ in $70 \%$ of all analyzed samples, whereas $8 \%$ where higher than $13 \mu \mathrm{g} / \mathrm{l}$ (chronic exposition guideline under current French regulation), 5\% higher than 20 $\mu \mathrm{g} / \mathrm{l}$ (WHO provisional guideline for recreative waters) and $2.5 \%$ higher than $80 \mu \mathrm{g} / \mathrm{l}$ (acute exposition guideline, current French regulation).

Annual data show that at regional scale $92 \%$ of monitoring weeks showed less than $50 \%$ of all samples with positive MCs detection (Figure 5), whereas in some cases (10 weeks in 8 years, i.e. $8 \%$ monitoring duration) more than $60 \%$ samples could show positive MCs detection. 
Minimal detection frequencies were observed in 2004, 2008 and 2011 with 30 to 50\% max. positive samples, whereas 2005, 2006, 2009 and 2010 could reach $100 \%$ positive detections during one week every year.

\section{Figure 5}

Annual peak detection frequencies never appeared to be synchronized with max. cell densities, but could be observed from 5 weeks earlier to 7 weeks later without definite pattern. In the same way, max. detection frequencies were offset relative to max. cell biovolumes: they were observed 5 to 8 weeks before peak biovolume from 2004 to 2007, and 3 to 7 weeks after peak biovolume from 2008 to 2011.

An inverse relation was found between cell density and MCs detection frequency (Figure 6a), as max. MCs detection frequencies ( $32 \%$ samples) appeared in the 50 to $100000 \mathrm{cell} / \mathrm{ml}$ range. The lowest detection frequencies (12-15\% samples) were encountered for cell densities higher than 200000 cell/ml. The maximal MCs concentrations, up to $234 \mu \mathrm{g} / \mathrm{l}$, were observed in the highest cell density samples (higher than $500000 \mathrm{cell} / \mathrm{ml}$ ). The MCs concentrations encountered from 50 to 100000 cell/ml, although lower, could however reach 16 to $22 \mu \mathrm{g} / \mathrm{l}$. In such cases MCs can exceed WHO guidelines for recreative waters and pose a health hazard to children and young adults. On the other hand, a positive relation was found between cell biovolume and MCs detection frequency (Figure 6b), reaching $27 \%$ positive MCs detections for $5.10^{6} \mu \mathrm{m}^{3} / \mathrm{ml}$, and a maximum of $31-33 \%$ positive detections above $5.10^{7} \mu \mathrm{m}^{3} / \mathrm{ml}$. This relation paralleled another positive relation between cell biovolume and MCs max concentrations reaching 11 to $32 \mu \mathrm{g} / \mathrm{l}$ from $5.10^{6}$ to $5.10^{7} \mu \mathrm{m}^{3} / \mathrm{ml}$, and 126 to $234 \mu \mathrm{g} / \mathrm{l}$ above $5.10^{7} \mu \mathrm{m}^{3} / \mathrm{ml}$.

Figure $6 a, 6 b$

\section{3- Alert level assessment}


From 2004 to 2011 WHO alert level 2 (20 000 cell/ml) was exceeded in $49 \%$ of all samples and MCs were detected in $22 \%$ of all samples reaching this threshold. In the same time, WHO alert level 3 was exceeded in $24 \%$ samples and MCs were detected in $20 \%$ of corresponding samples.

The data for 2004-2011 show that MCs could be detected (i.e. $>0.2 \mu \mathrm{g} / \mathrm{l}$ ) in samples with cell densities as low as $340 \mathrm{cell} / \mathrm{ml}$. On the other hand, the minimal cell density for $1 \mu \mathrm{g} / \mathrm{l} \mathrm{MCs}$ was 9259 cell/ml (i.e. $62 \%$ samples), and 11680 cell $/ \mathrm{ml}$ (i.e. 65\% samples) for $20 \mu \mathrm{g} / \mathrm{l} \mathrm{MCs.} \mathrm{Searching} \mathrm{for} \mathrm{MCs}$ when cell density reaches these values would result in a regional monitoring cost multiplied by 1.5 and 1.6 in comparison with analyses for cell densities higher than WHO alert 3.

These results show that MCs monitoring protocols based on high cell densities tend to underestimate toxin presence, questioning cell density relevance as a risk indicator. On the other hand, the positive relations underlined between cell biovolume, MCs detection frequency and MCs concentrations can be used for risk management in the full range of cyanobacteria concentration, from the lowest (i.e. the most numerous cases) to the highest cell densities.

According to the relations underlined between cell biovolume, MCs detections and MCs concentrations, the minimal biovolume necessary to observe target MCs concentrations (TMC) can be calculated (Figure 7), thus allowing for novel alert levels definition.

Figure 7

Alert levels corresponding to target MCs concentrations can be, in our case, graphically derived from figure 7, The cell biovolume thresholds corresponding to MCs concentrations of 1 and $20 \mu \mathrm{g} / \mathrm{l}$ were determined to be $455000 \mu \mathrm{m}^{3} / \mathrm{mland} 4500000 \mu \mathrm{m}^{3} / \mathrm{ml}$ respectively.

Searching MCs with a TMC $=1 \mu \mathrm{g} / \mathrm{l}$ in samples with a biovolume higher than $450000 \mu \mathrm{m} 3 / \mathrm{ml}$, i.e. $56 \%$ of all samples, would lead to $23 \%$ positive detections for a regional cost index of 1.4 compared to $\mathrm{WHO}$ alert level 3. Setting the TMC at $20 \mu \mathrm{g} / \mathrm{l}$ and $4500000 \mu \mathrm{m}^{3} / \mathrm{ml}$, i.e. $22 \%$ samples, would lead 
to $26 \%$ positive detection with a regional cost index of 0.97 , similar to the current monitoring cost based on WHO alert level 3.

Further comparisons between biovolume thresholds and low cell density samples show that:

- 30\% of all samples had a cell biovolume higher than $450000 \mu \mathrm{m}^{3} / \mathrm{ml}$ and cell density lower than 100000 cell/ml. Positive MCs detections occurred in $37 \%$ of these samples.

- $5 \%$ of all samples had a cell biovolume higher than $4500000 \mu \mathrm{m}^{3} / \mathrm{ml}$ and cell density lower than 100000 cell/ml. Positive MCs detections occurred in 51\% of these samples.

- Conversely $0.8 \%$ of all samples had a cell density higher than 100000 cell/ml and a biovolume lower than $450000 \mu \mathrm{m}^{3} / \mathrm{ml}$. None of them was positive for MCs.

\section{4- Conclusion}

In France as in most other countries where cyanobacteria are monitored, MCs monitoring in recreational waters is focused on proliferation episodes estimated through cell densities analysis, and MCs analysis is mandatorily required above $\mathrm{WHO}$ alert level 3, i.e. $100000 \mathrm{cell} / \mathrm{ml}$. As analyses are optional below WHO Alert Level 3, data on toxin occurrence for low cell densities are scarce and public health managers can question this threshold relevance with regard to microcystin exposure estimation. Chorus and Bartram (1999) insisted on the necessary local assessment and validation of WHO guidelines. Local adaptation can then lead to new decision frameworks, with the use of different alert levels based on cell densities or cell biovolume (Ibelings et al., 2014) or other biomass proxies (Watzin et al., 2006; Rogalus and Watzin, 2008).

In our view, a public health cyanobacteria-MCs monitoring protocol must be representative of all including subacute- exposition situations. The simplest solution to achieve this would be systematic analysis of cyanobacteria and toxin concentrations. However, this is impossible because of cost issues. As the samples analyzed for toxin concentration must be selected, the selection process must conduct to the highest possible toxin detection frequency in all selected samples. 
The present study allowed a comparison between cell density and cell biovolume as indicators of microcystin exposure in recreational waters. Our results show that a monitoring protocol based on cell density thresholds matches available observations from the literature related to acute MCs concentrations: the highest MCs concentrations are encountered in the highest cell density or biovolume samples. From this point of view, using biovolume as an indicator doesn't bring much supplementary information.

Using cell biovolume seems however adapted to the most numerous cases in Brittany, for cyanobacteria cell densities lower than WHO alert level 3, when risks are not considered by water users, i.e. no bloom, no green coloration... no 'hazard' feeling (Hunter et al., 2012). In these cases toxin detection frequencies are the highest and microcystin concentrations can be a health hazard for children and young adults. A MCs monitoring based on cell biovolumes seems better suited to account for toxin exposure than the classical cell density scheme.

Cell biovolume thresholds can be defined to account for target MCs concentrations (TMC) while maintaining analytical costs similar to the actual monitoring scheme at regional scale. Cost index may however vary from lake to lake, as higher cell densities and higher cell biovolumes are not always encountered in the same sites. In the present study $30 \%$ of all samples had high biovolumes and low cell densities (with TMC $=1 \mu \mathrm{g} / \mathrm{l}$ ), meaning that part of the monitoring cost would be redistributed from higher densities/lower biovolume lakes to lower densities/higher biovolumes lakes.

The present results were obtained in an oceanic climate context, in mostly eutrophic lakes, with highly diverse planktonic populations. Cyanobacteria taxonomic composition and MCs production can be affected by various abiotic parameters such as meteorology (light, temperature: Wiedner et al., 2007; Pitois et al., 2014b; Rigosi et al., 2015), hydrology (Carvalho et al., 2011) or nutrient balance (Dolman et al., 2012), and even synergistic inter-species activity (Garcia Nieto et al., 2011). The method for cell biovolume alert levels should be validated on a larger geographical basis, as the proposed biovolume thresholds will not necessarily be relevant in other climatic or trophic conditions. 


\section{Acknowledgments}

This work is part of the ORACLE project funded by the French National Agency of Sanitary Security (ANSES) under the national program of Environment-Health-Work research (PNRSET 2012, projet 11115). The authors sincerely thank the French Agence Régionale de Santé (ARS) of Brittany, the Agence de l'Eau Loire-Bretagne (AELB), the Health \& Environment department of Rennes city and the Syndicat Mixte de Production du Bassin Rennais (SMPBR) for kindly providing the source data.

\section{References}

Backer, L. C., Carmichael, W., Kirkpatrick, B., Williams, C., Irvin, M., Zhou, Y., Johnson, T., Nierenberg, K., Hill, V., kieszak, S., Cheng, Y. S., 2008. Recreational exposure to low concentrations of microcystins during an algal bloom in a small lake. Mar. Drugs 6, 389-406

Backer, L. C., Mcneel, S. V., Barber, T., Kirkpatrick, B., Williams, C., Irvin, M., Zhou, Y., jonhson, T., Nirenberg, K., Aubel, M., Leprell, R., Chapman, A., Foss, A., Corum, S., Hill, V., Kieszak, S., Cheng, Y., 2010. Recreational exposure to microcystins during algal blooms in two California lakes. Toxicon 55(5), 909-921

Byth, S., 1980. Palm Island mystery disease. Med. J. Aust. 2, 40-2

Carvalho, L., Miller née Ferguson, C., Scott, E. M., Codd, G., Davies, P. S., Tyler, A. N., 2011. Cyanobacterial blooms: statistical models describing risk factors for national-scale lake assessment and lake management. Sci. Total Environ. 409(24), 5353-5358

Cheng, Y. S., Zhou, Y., Irvin, C. M., Kirkpatrick, B., Backer, L. C., 2007. Characterization of aerosols containing microcystin. Mar. Drugs 5(4), 136-50

Chorus, I., Bartram, J., 1999. Toxic Cyanobacteria in Water: A Guide to Their Public Health Consequences, Monitoring and Management. E \& FN Spon, London

Codd, G.A., Morrison, L.M., Metcalf, J.S., 2005. Cyanobacterial toxins: risk management for health protection. Toxicol. Appl. Pharm. 203, 264-272 
Dolman, A. M., Rücker, J., Pick, F. R., Fastner, J., Rohrlack, T., Mischke, U., Wiedner, C., 2012. Cyanobacteria and Cyanotoxins: The Influence of Nitrogen versus Phosphorus. PLoS ONE 7(6), e38757

Falconer, I. R., Burch, M. D., Steffensen, D. A., Choice, M., Coverdale, O. R., 1994. Toxicity of the bluegreen alga (cyanobacterium) Microcystis aeruginosa in drinking water to growing pigs, as an animal model for human injury and risk assessment. Environ. Toxicol. Water Qual. 9, 131-139

Garcia Nieto, P. J., Sánchez Lasheras, F., de Cos Juez, F. J., Alonso Fernández, J. R., 2011. Study of cyanotoxins presence from experimental cyanobacteria concentrations using a new data mining methodology based on multivariate adaptive regression splines in Trasona reservoir (Northern Spain). J. Hazard. Mater. 195, 414-421.

Geitler, L., 1932. Cyanophyceae von Europa, Kryptogamen Flora von Deutschland, Osterreich und der Schweiz, Koeltz Scientific Books: Koeningstein, Germany

Gilroy, D. J., Kauffman, K. W., Hall, R. A., Huang, X., Chu, F. S., 2000. Assessing potential health risks from microcystin toxins in blue-green algae dietary supplements. Environ. Health Perspect. 108, 435439

Griffiths, DJ., Saker, M.L., 2003. The Palm Island mystery disease 20 years on: a review of research on the cyanotoxin cylindrospermopsin. Environ. Toxicol. 18, 78-93

Heussner, H., Mazija, L., Fastner, J., Dietrich, D. R., 2012. Toxin content and cytotoxicity of algal dietary supplements. Toxicol. Appl. Pharma. 265(2), 263-271

Hunter, P. D., Hanley, N., Czajkowski, M., Mearns, K., Tyler, A. N., Carvalho, L., Codd, G., 2012. The effect of risk perception on public preferences and willingness to pay for reductions in the health risks posed by toxic cyanobacterial blooms. Sci. Total Environ. 426, 32-44

Ibelings, B.W., Backer L.C., Kardinaal, W.E.A., Chorus, I., 2014. Current approaches to cyanotoxin risk assessment and risk management around the globe. Harmful Algae 40, 63-74

Ibelings, B. W., Chorus, I., 2007. Accumulation of cyanobacterial toxins in freshwater "seafood" and its consequences for public health: a review. Environ. Poll. 150(1), 177-192 
Kirkpatrick, B., Fleming, L. E., Bean, J. A., Nierenberg, K., Backer, L. C., Cheng, Y. S., Baden, D. G., 2011. Aerosolized red tide toxins (brevetoxins) and asthma: Continued health effects after $1 \mathrm{~h}$ beach exposure. Harmful Algae 10(2), 138-143

Kirkpatrick, B., Pierce, R., Cheng, Y. S., Henry, M. S., Blum, P., Osborn, S., Baden, D., 2010. Inland transport of aerosolized Florida red tide toxins. Harmful Algae 9, 186-189

Komarek, J., 2013. Süßwasserflora von Mitteleuropa, Bd. 19/3: Cyanoprokaryota: 3. Teil / 3rd part: Heterocytous Genera. Büdel, B., Gärtner, G., Krieinitz, L., Shagerl, M. (Eds), Süßwasserflora von Mitteleuropa, Spektrum Academischer Verlag: Heidelberg, Germany

Komarek, J., Anagnostidis, K., 1999. Cyanoprokaryota 19/1. Teil: Chroococcales. Ettl, H., Gärtner, G., Heynig, H., Mollenhauer, D. (Eds), Süßwasserflora von Mitteleuropa, Spektrum Academischer Verlag: Heidelberg, Germany

Komarek, J., Anagnostidis, K., 2005. Cyanoprokaryota 19/2. Teil: Oscillatoriales. Büdel, B., Gärtner, G., Krienitz, L., Schagerl, M. (Eds.), Süßwasserflora von Mitteleuropa, Spektrum Academischer Verlag: Heidelberg, Germany

Rogalus, M. K., Watzin, M. C., 2008. Evaluation of sampling and screening techniques for tiered monitoring of toxic cyanobacteria in lakes. Harmful Algae 7, 504-514

Lawrence, J.F., Niedzwiadek, B., Menard, C., Lau, B.P., Lewis, D., Kuper-Goodman, T., Holmes, C., 2001. Comparison of liquid chromatography/mass spectrometry, ELISA, and phosphatase assay for the determination of microcystins in blue-green algae products. J. AOAC Int. 84, 1035-1044 Li, Y., Chen, J., Zhao, Q., Pu, C., Qiu, Z., Zhang, R., Shu, W., 2011. A Cross-Sectional Investigation of Chronic Exposure to Microcystin in Relationship to Childhood Liver Damage in the Three Gorges Reservoir. Environ. Health Persp. 119(10), 1483-1488

Merel, S., Walker D., Chicana, R., Snyder, S., Baurès, E., Thomas O., 2013. Occurrence and management of harmful cyanobacterial blooms in surface water and drinking water treatment. Env. Int. 59, 303-327 
Ohkouchi, Y., Tajima, S., Nomura, M., Itoh, S., 2015. Inflammatory responses and potencies of various lipopolysaccharides from bacteria and cyanobacteria in aquatic environments and water supply systems. Toxicon 97, 23-31

Osborne, N. J., Shaw, G. R., Webb, P. M., 2007. Health effects of recreational exposure to Moreton Bay, Australia waters during a Lyngbya majuscula bloom. Env. Int. 33(3), 309-314

Pilotto, L., Hobson, P., Burch, M. D., Ranmuthugala, G., Attewell, R., Weightman, W., 2004. Acute skin irritant effects of cyanobacteria (blue-green algae) in healthy volunteers. Australian and New Zealand J. Public Health 28(08), 220-224

Pitois, F., Thomas, O., Thoraval, I., Baurès, E., 2014a. Learning from 8 years of regional cyanobacteria observation in Brittany in view of sanitary survey improvement. Environment International $62,113-$ 118

Pitois, F., Thoraval, I., Baurès, E., Thomas, O., 2014b. Geographical Patterns in Cyanobacteria Distribution: Climate Influence at Regional Scale. Toxins 6(2), 509-522

Rellán, S., Osswald, J., Saker, M., Gago-Martinez, A., Vasconcelos, V. M., 2009. First detection of anatoxin-a in human and animal dietary supplements containing cyanobacteria. Food Chem. Toxicol. 47(9), 2189-2195

Rigosi, A., Hanson, P., Hamilton, D. P., Hipsey, M., Rusak, J. A., Bois, J., Sparber, K., Chorus, I., Watkinson, A., Qin, B., Kim, B., Brookes, J. D., 2015. Determining the probability of cyanobacterial blooms : the application of Bayesian networks in multiple lake systems. Ecol. Appl. 25(1), 186-199 Spoof, L., 2005. Microcystins and nodularins. In: Jussi Meriluoto and Geoffrey A. Codd (Eds.), Toxic Cyanobacterial Monitoring and Cyanotoxin Analysis, Åbo Akademi University Press, pp. 15-40.

Stewart, I., Webb, P. M., Schluter, P. J., Shaw, G. R., 2006. Recreational and occupational field exposure to freshwater cyanobacteria - a review of anecdotal and case reports, epidemiological studies and the challenges for epidemiologic assessment. Environ. Health 5(1), 6

Sychrová, E., Štěpánková, T., Nováková, K., Bláha, L., Giesy, J. P., Hilscherová, K., 2012. Estrogenic activity in extracts and exudates of cyanobacteria and green algae. Env. Int. 39(1), 134-40 
US Environmental Protection Agency (US EPA), 2010. LG 401-Standard Operating Procedure for Phytoplankton Analysis, EPA: Chicago, IL, USA

Utermöhl, H., 1958. Zur Vervollkommnung der quantitativen Phytoplankton-Methodik. Mitt. Int. Ver. Theor. Angew. Limnol., 9, 1-38

Vichi, S., Lavorini, P., Funari, E., Scardala, S., Testai, E., 2012. Contamination by Microcystis and microcystins of blue-green algae food supplements (BGAS) on the italian market and possible risk for the exposed population. Food Chem. Toxicol. 50(12), 4493-4499

Watzin, M., Miller, E., Shambaugh, A., Kreide, M., 2006. Application of the WHO Alert Level Framework to Cyanobacterial Monitoring of Lake Champlain, Vermont. Env. Toxicol. 21(3), 278-288

Weirich, C. A., Miller, T. R., 2014. Freshwater Harmful Algal Blooms: Toxins and Children's Health. Curr. Prob. Pediat. Adol. Health Care 44(1), 2-24

Wiedner, C., Rücker, J., Brüggemann, R., Nixdorf, B., 2007. Climate change affects timing and size of populations of an invasive cyanobacterium in temperate regions. Oecologia 152(3), 473-484

Young, F. M., Micklem, J., \& Humpage, A. R., 2008. Effects of blue-green algal toxin cylindrospermopsin (CYN) on human granulosa cells in vitro. Reprod. Toxicol. 25(3), 374-80

Zegura, B., Straser, A., \& Filipič, M., 2011. Genotoxicity and potential carcinogenicity of cyanobacterial toxins - a review. Mutat. Res. 727(1-2), 16-41 


\section{Figure captions}

Figure 1: Spatial distribution of the 26 investigated sites in Brittany (France).

Figure 2: Mean weekly cell densities from June 2004 to September 2011.

Figure 3: Mean weekly cell biovolumes from June 2004 to September 2011.

Figure 4: Cyanobacteria generic composition evolution from June 2004 to September 2011.

Figure 5: MCs and weekly detection frequencies from June 2004 to September 2011.

Figure 6: Microcystin detection frequencies vs. cell densities (a) and cell biovolume (b). Only class means are illustrated for better clarity.

Figure 7: Minimal biovolume thresholds relation with target MCs concentrations.

\section{Manuscript highlights}

- Toxic cyanobacteria data were collected from an 8-years regional public health survey

- Microcystin exposure was estimated in the raw waters from 26 lakes

- Subacute toxin concentrations more frequently encountered than acute concentrations

- Alert levels based on cell densities and cell biovolumes are compared in view of a better exposure representativity 
Figure 1
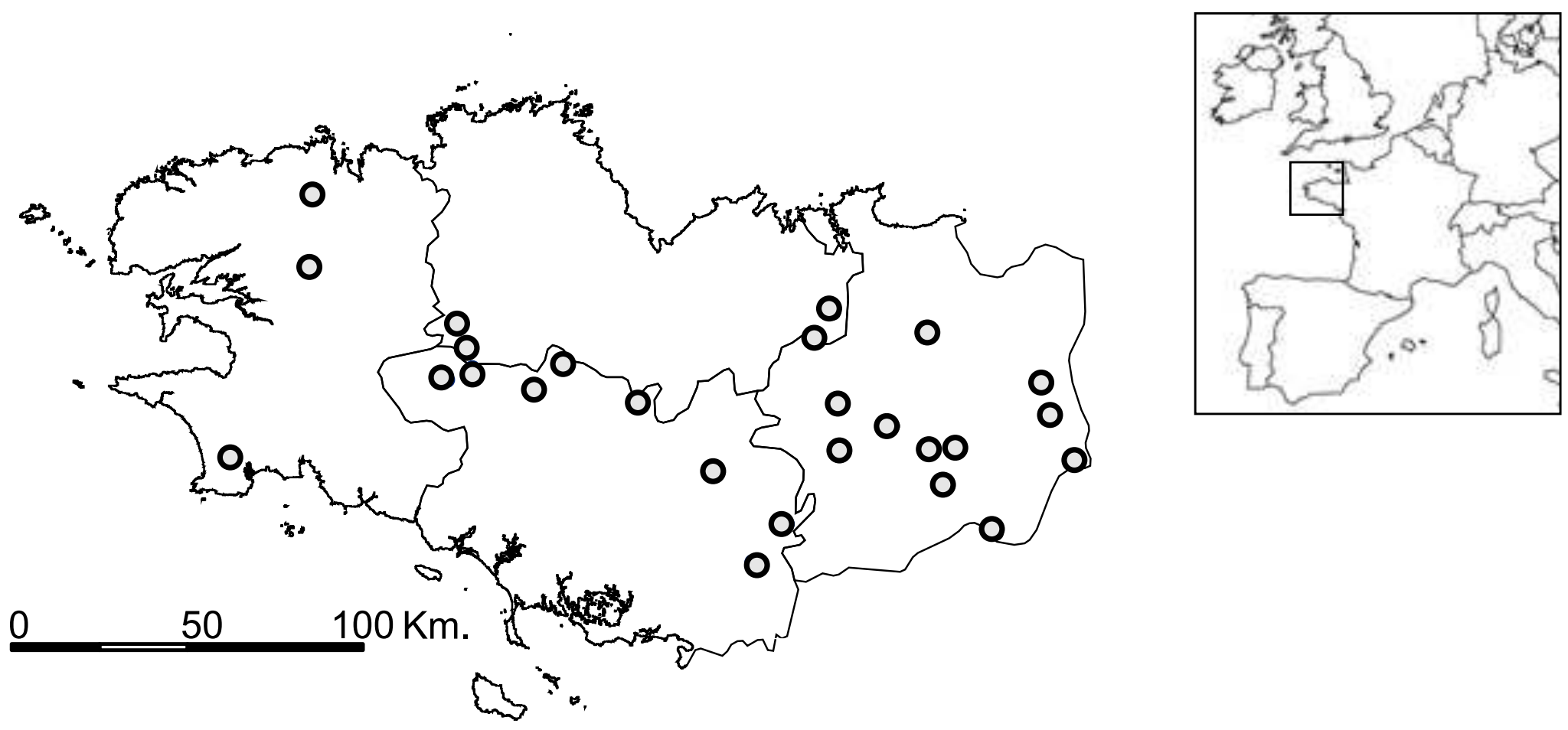

son. 


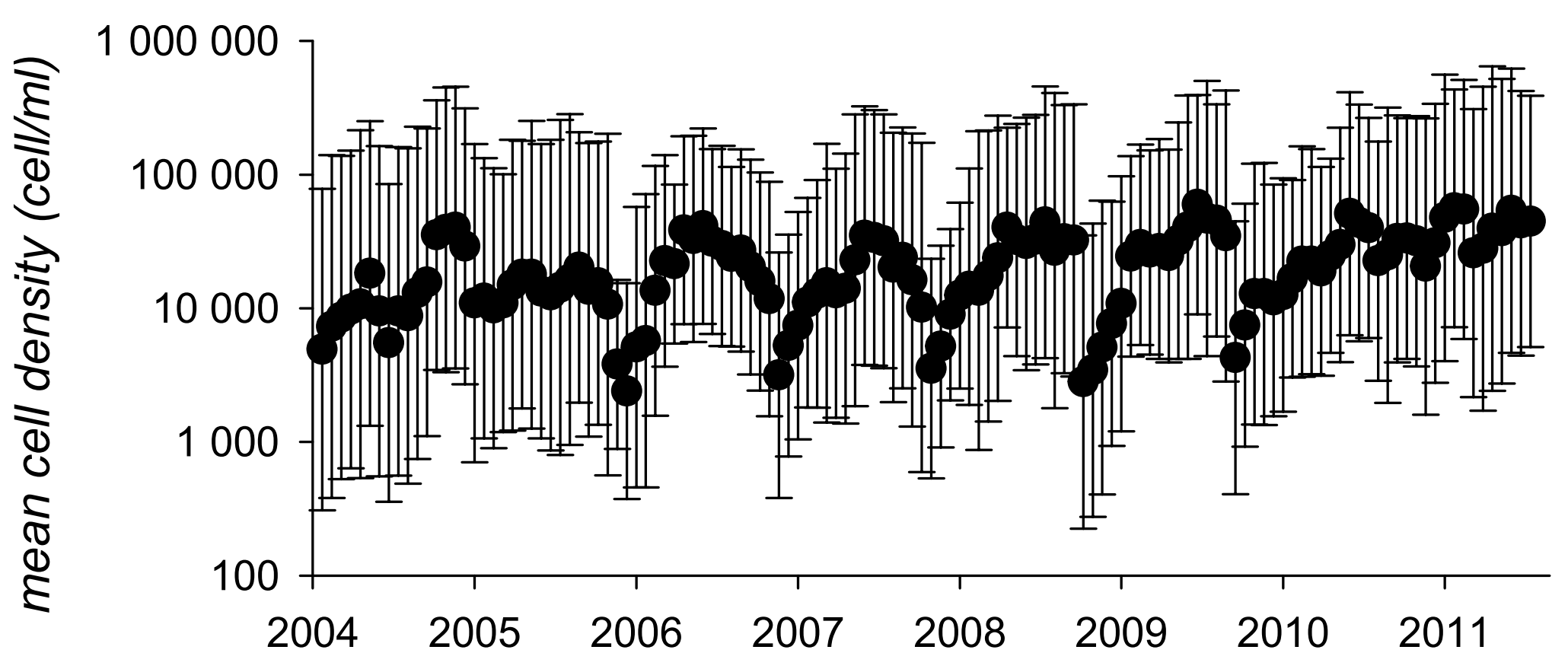




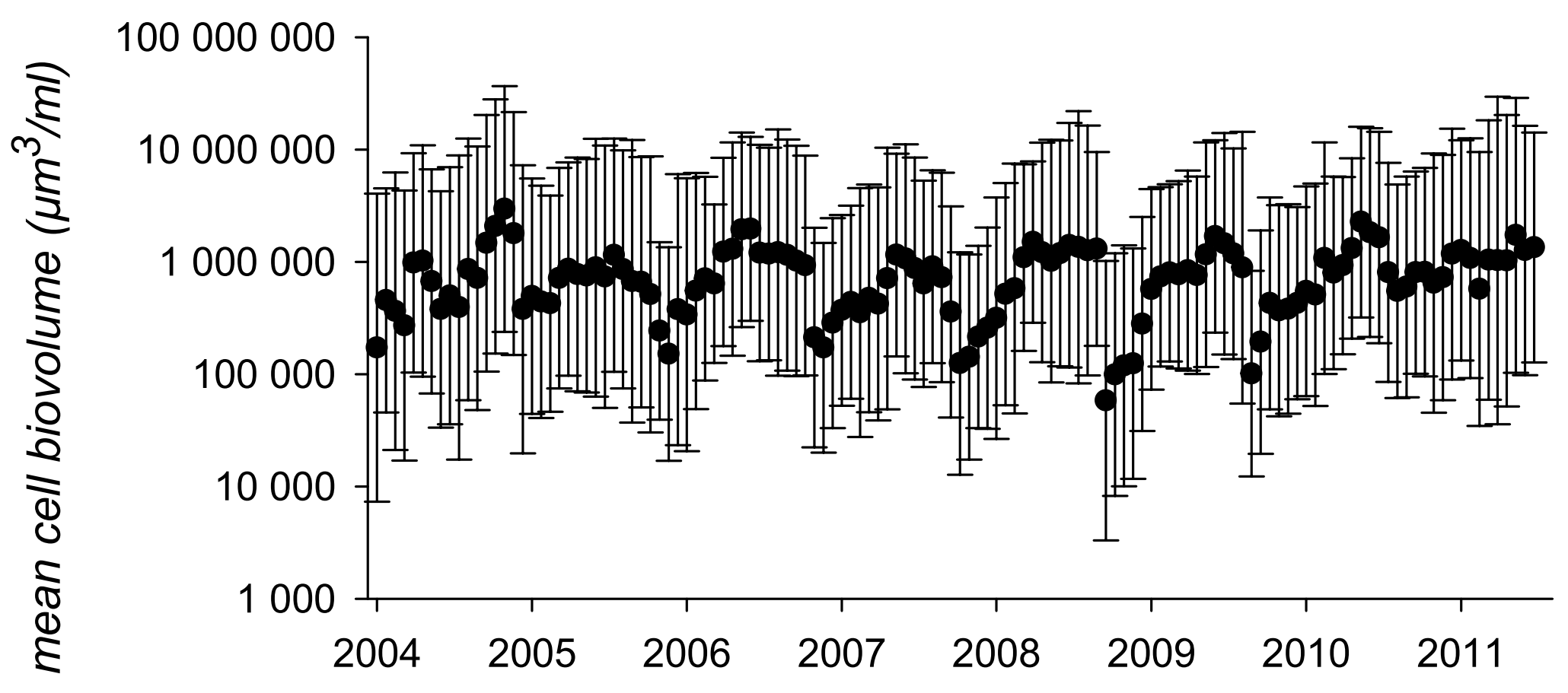


Figure 6b
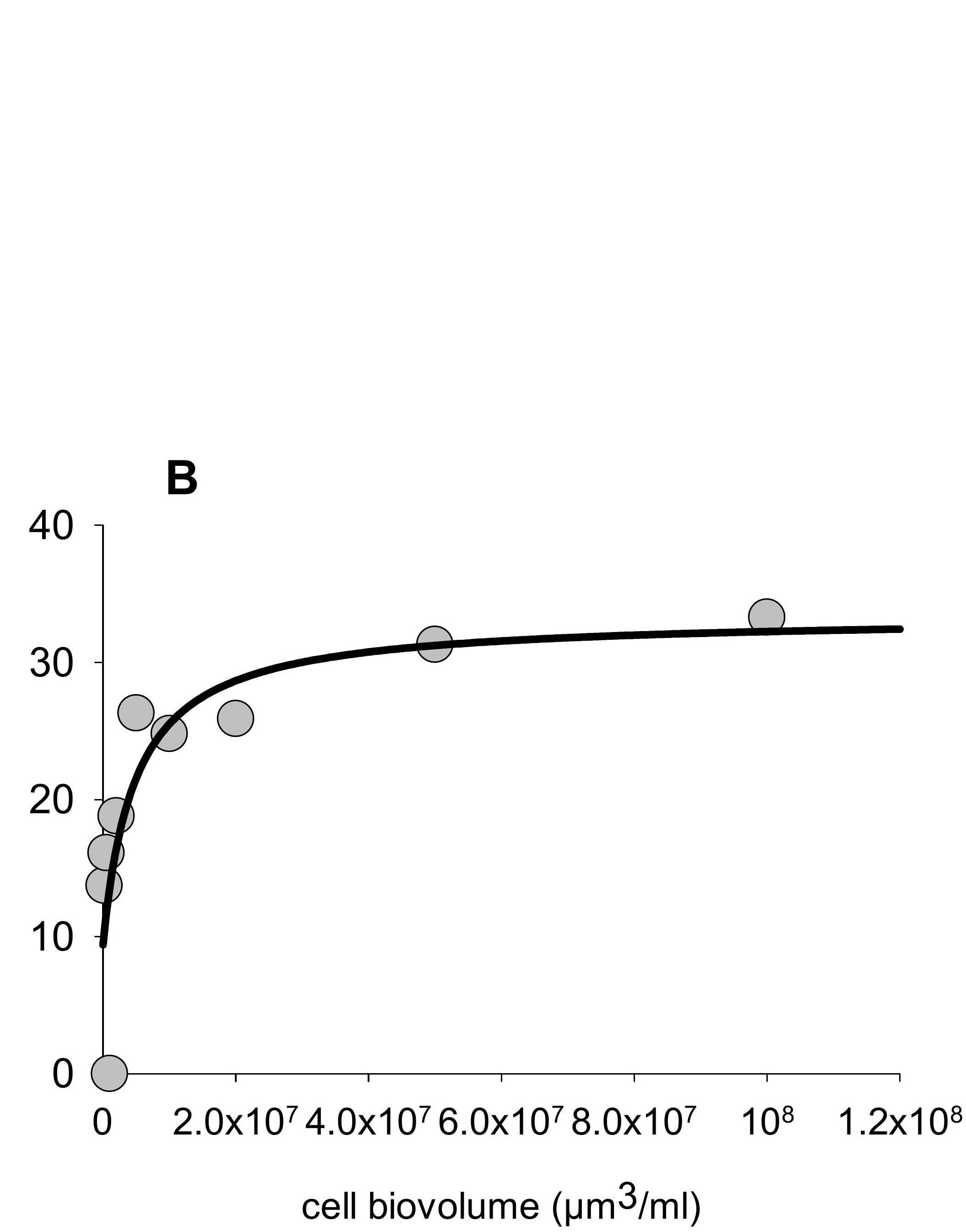


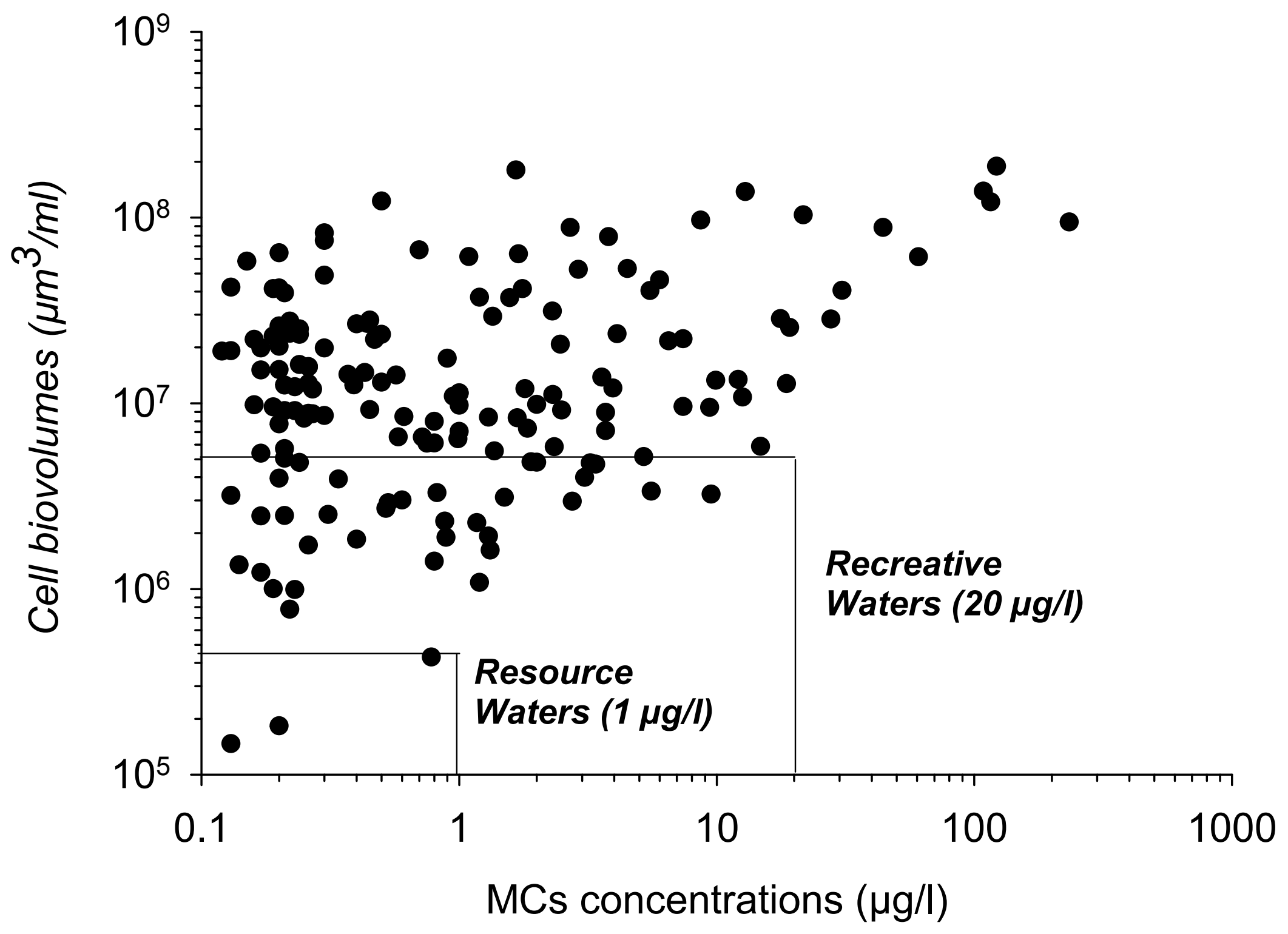

